\title{
Pengaruh Karakteristik Psikologi terhadap Intensi Kewirausahaan di mediasi Sikap Kewirausahaan (Studi pada Mahasiswa di Lima Universitas Yogyakarta)
}

\author{
Gesa Sekar Risanti ${ }^{1}$ \\ ${ }^{1}$ PT Indotrade Multiniaga, Sukoharjo, Jawa Tengah \\ gesasekar@outlook.com \\ DOI: https://doi.org/10.24071/exero.v3i2.4299
}

\begin{abstract}
Abstrak
Penelitian ini bertujuan untuk mengidentifikasi karateristik perilaku, kewirausahaan, dan kewirausahaan pada mahasiswa dari lima universitas di Yogyakarta dan menjelaskan bagaimana karakteristik psikologi mempengaruhi niat kewirausahaan yang di mediasi oleh sikap kewirausahaan. Populasi dalam penelitian ini adalah semua mahasiswa dari Gadjah Mada, Universitas Islam Negeri Sunan Kalijaga, Universitas Sanata Dharma, Universitas Atma Jaya Yogyakarta, dan Universitas Sarjanawiyata. Metode pengambilan sample dengan incidental sampling. 100 responden berpartisipasi dalam penelitian ini sebagai mata pelajaran riset. Namun, hanya 98 dari 100 data dapat dianalisis lebih lanjut. Teknik analisis dalam penelitian ini menggunakan SPSS 22.0 untuk Windows. Hasil dari penelitian ini menunjukkan efek dari karakteristik psikologis pada niat kewirausahaan yang diperantarai oleh sikap kewirausahaan.
\end{abstract}

Kata kunci: karakteristik psikologi, sikap kewirausahaan, niat berwirausaha

\begin{abstract}
This research aims to identify psychological characteristics, entrepreneurial attitudes and entrepreneurial intentions on students of five universities in Yogyakarta and explain how pychological characteristics affect entrepreneurial intentions which is mediated by entrepreneurial attitudes. Population in this research is all students of Universitas Gadjah Mada, Universitas Islam Negeri Sunan Kalijaga, Universitas Sanata Dharma, Universitas Atma Jaya Yogyakarta and, Universitas Sarjanawiyata Tamansiswa. Sampling method which is applied in this research is incidental sampling. 100 respondents participate in this research as the research subjects. However, only 98 out of 100 data can be analyzed further. The analysis technique employed in this research is path analysis operating SPSS 22.0 for windows. The result of this research indicates the effect of psychological characteristics on entrepreneurial intentions which is mediated by entrepreneurial attitudes.
\end{abstract}

Keywords: psychological characteristics, entrepreneurial attitudes, and entrepreneurial intentions

\section{Pendahuluan}

Kewirausahaan menjadi salah satu instrumen yang penting bagi pertumbuhan dan perkembangan ekonomi di berbagai negara. Semakin tinggi tingkat wirausaha disebuah negara semakin rendah tingkat pengangguran di negara tersebut, dengan kata lain kewirausahaan memiliki peran dalam memerangi pengangguran. Wirausaha juga merupakan salah satu penentu suatu negara dikatakan maju ditinjau dari jumlahnya. Bank dunia menyatakan bahwa syarat suatu negara dikatakan memiliki perekonomian yang baik dan maju adalah minimal 4 persen warganya berwirausaha 
(Kompas Online, 2018). Scarborough dan Zimmerer (dalam Bux dan Honglin, 2015) mengatakan bahwa kewirausahaan adalah salah satu mesin penggerak pertumbuhan ekonomi, inovasi dan kompetisi berbagai negara.

Namun jumlah wirausahawan di Indonesia saat ini baru mencapai angka 3,1 $\%$ dari jumlah penduduk (https://money.kompas.com/read/2019). Angka tersebut masih jauh tertinggal dari negara - negara tetangga, di mana Malaysia 5\%, Singapura $7 \%$, dan Jepang $11 \%$ dari jumlah penduduk. Tingkat kewirausahaan di Indonesia saat ini menduduki peringkat 97 dari 137 negara (https://republika.co.id). Hal tersebut tentunya menimbulkan keprihatinan dari berbagai kalangan. Oleh sebab itu diperlukan peran dari berbagai pihak untuk mendorong semakin banyak masyarakat agar melakukan tindakan wirausaha.

Townsend et al (2010) mengatakan bahwa niat wirausaha secara langsung maupun tidak langsung adalah cikal bakal dari tindakan wirausaha, meskipun tidak selalu niat berasal dari suatu tindakan. Dengan kata lain niat yang dimiliki seseorang dalam berwirausaha akan mendorong tindakan berwirausaha di masa yang akan datang. Oleh karena itu penting di masa sekarang untuk membentuk niat atau intensi seseorang untuk berwirausaha. Baron dan Kenny 1986 (dalam Kusmintarti et al. 2014) menyatakan bahwa sikap kewirausahaan bertindak sebagai penguat karakteristik kewirausahaan yang memengaruhi niat kewirausahaan. Rush dan Ferse (dalam Sharaf et al. 2018) menyatakan bahwa locus of control, propensity to take risk, self-efficacy, need for achievement, tolerance for ambiguity dan inovasi adalah karakteristik psikologi yang terkait dengan kewirausahaan yang akan memprediksi sikap kewirausahaan.

Namun fitur atau karakteristik setiap orang tentunya memiliki pola yang berbeda - beda. Sebab setiap pribadi adalah unik dalam pekerjaan maupun hidupnya. Selain karakteristik yang berbeda-beda, sikap dan intensi seseorang dalam berwirausaha juga tentunya berbeda- beda. Sardshmak dan Smith (2010) mengatakan bahwa dalam pembentukan niat / intensi wirausaha penting untuk memahami perilaku wirausaha. Dari setiap perbedaan yang dimiliki setiap orang tersebut tentu ada pola karakteristik tertentu yang berhubungan dengan sikap kewirausahaan dan selanjutnya memengaruhi intensi seseorang untuk berwirausaha. 
Berdasarkan latar belakang di atas, penelitian dengan judul "Pengaruh Karakteristik Psikologi terhadap Intensi Kewirausahaan Dimediasi Sikap Kewirausahaan" (Studi pada Mahasiswa Lima Universitas di Yogyakarta) ini dilakukan.

\section{Kajian Literatur}

\section{Kewirausahaan}

Ireland dan Barringer (2016:28) mendefinisikan kewirausahaan sebagai process by which individuals pursue opportunities without regard to resources they currently control for the purpose of exploiting future goods and services. Agustina (2019:8) mengemukakan kewirausahaan adalah sifat lahiriah yang ada pada setiap orang. Lingkunganlah yang membedakan satu orang dengan yang lainnya. Memiliki bakat berwirausaha saja belumlah cukup untuk menjadi pengusaha. Dibutuhkan latihan dan tempaan untuk memiliki jiwa entrepreneur yang unggul.

Edvarson (dalam Agustina, 2019:3-4) mendefinisikan kewirausahaan sebagai perilaku-perilaku yang dinamis, pengambilan risiko, reaktif dan berorientasi pada pertumbuhan, kewirausahaan adalah orang yang bersedia mengambil tindakan untuk mengejar peluang dalam situasi yang dipandang sebagai masalah atau ancaman.

Hisrich, Peters dan Shepherd 2005 (dalam Bux dan Honglin, 2015) kewirausahaan adalah proses menciptakan sesuatu yang baru dengan nilai dengan mencurahkan waktu dan upaya yang diperlukan, dengan asumsi risiko keuangan, psikis dan sosial yang menyertainya dan menerima imbalan yang dihasilkan.

Dari beberapa pendapat di atas dapat disimpulkan bahwa kewirausahaan merupakan proses individu dalam menciptakan dan mengejar peluang atau sesuatu yang baru dengan mencurahkan waktu dan upaya tanpa takut mengambil risiko keuangan, psikis, sosial maupun sumberdaya lainnya, dengan tujuan untuk mengusahakan imbalan, barang, maupun jasa di masa depan

\section{Intensi Kewirausahaan}

Bird 1988 (dalam Bux dan Honglin, 2015) mendefinisikan intensi kewirausahaan sebagai state of mind which directs and guides the action of the individual towards the development and implementation of new business concepts. 
Menurut Fini et al. 2009 (dalam Kusmintarti et al, 2014) intensi kewirausahaan adalah sebagai representasi kognitif dari tindakan yang harus dilaksanakan oleh individu untuk membangun usaha mandiri baru atau untuk menciptakan nilai baru dalam perusahaan yang sudah ada. Kusmintarti et al. (2014) mengemukakan dalam studinya bahwa niat kewirausahaan sebagai representasi kognitif dari tindakan yang akan dilakukan seseorang untuk membangun bisnis baru.

Dari beberapa pendapat di atas dapat disimpulkan bahwa intensi kewirausahaan adalah kondisi pikiran yang mengarah dan membimbing pada tindakan individu untuk membangun, mengembangkan dan mengimplementasikan bisnis baru

\section{Indikator Intensi Kewirausahaan}

Menurut Kusmintarti et al. (2014) indikator intensi kewirausahaan mencakup : (1) motivasi untuk membangun bisnis setelah lulus (2) motivasi untuk membangun bisnis di masa depan motivasi untuk merealisasikan bisnis (4) motivasi membangun bisnis setelah memiliki modal finansial (5) motivasi untuk membangun bisnis berdasarkan jejaring sosial

\section{Karakteristik Psikologi}

Menurut Mathiue dan Zajac 1990 (dalam Rusdiana, 2014:117), karakteristik adalah personal (individu) mencakup usia, jenis kelamin, masa kerja, tingkat pendidikan, suku bangsa dan kepribadian. Siagian 2008 (dalam Rusdiana, 2014:118) mengemukakan bahwa karakteristik biografikal (individu) dapat dilihat dari umur, jenis kelamin, status perkawinan, jumlah tanggungan dan masa kerja. Dalam Kamus Besar Bahasa Indonesia yang dimaksud dengan karakteristik adalah mempunyai sifat khas sesuatu dengan karakteristik tertentu.

Menurut Grader Murphy 1929 (dalam Sarwono, 2009:6) Psikologi adalah ilmu yang mempelajari respons yang diberikan oleh makhluk hidup terhadap lingkungannya. Boring, Edwin G., Herbert S. Langfeld, Harry P. Weld, 1948 (dalam Sarwono, 2009:6) mengemukakan bahwa psikologi adalah studi tentang hakikat manusia. Clifford T Morgan 1966 (dalam Sarwono, 2009:6) mengatakan bahwa psikologi adalah ilmu yang mempelajari tingkah laku manusia dan hewan. 
Sedangkan menurut (Sarwono, 2009:7) dalam bukunya mengemukakan psikologi adalah ilmu pengetahuan yang mempelajari perilaku manusia dalam hubungan dengan lingkungannya.

Rush dan Ferse (dalam Sharaf et al. 2018) menyatakan bahwa locus of control, propensity to take risk, self-efficacy, need for achievement, tolerance for ambiguity dan inovasi adalah karakteristik psikologi yang terkait dengan kewirausahaan yang akan memprediksi sikap kewirausahaan. Kusmintarti et al. (2014) menyatakan bahwa seseorang yang memutuskan untuk memilih kewirausahaan sebagai pilihan kariernya harus memiliki internal locus of control (Rotter dalam Shane, et al. 2003) ; need for achievement (McClelland dalam Kobia dan Sikalieh, 2010) ; creativity (Birdthistle, 2008) ; social networking (Taormania dan Lao, 2007); propensity to risk ( Begley, 1995) ; tolerance for ambiguity (Sexton dan Bowman, 1985).

Fitur psikologi yang terkait dengan intensi wirausaha, yang disampaikan oleh Bygrave 1989 (dalam Bux dan Honglin, 2015) mencakup tolerance for ambiguity, internal locus of control, need for achievement dan propensity to take a risk. Menurut Gartner (1989); Basu dan Altinay (2002); Kusmintarti et al. (2014), karakteristik kewirausahaan adalah kombinasi dari beberapa karakteristik yang harus dimiliki oleh seorang wirausaha dan beberapa atribut psikologi dianggap sebagai prediktor niat wirausaha.

\section{Dimensi dan Indikator Karakteristik Psikologi}

\section{1) Dimensi Tolerance for Ambiguity}

Menurut Zimmerer et al. 2008 (dalam Kusmintarti et al. 2014) tolerance for ambiguity adalah kepribadian yang memengaruhi cara mengelola informasi tentang situasi ambigu. Sexton dan Bowman (dalam Kusmintarti et al. 2014) mengatakan bahwa di situasi yang ekstrem, ambiguitas seperti sesuatu yang tidak terprediksi, penuh dengan tekanan, dan ancaman. Disisi lain, tolerance for ambiguity / toleransi terhadap ambiguitas dianggap sebagai sesuatu yang diharapkan dan merupakan tantangan terhadap tujuan.

(Koh, 1996) mengatakan bahwa ketika informasi tidak cukup untuk menyusun sebuah situasi maka dapat dikatakan situasi ambigu sedang terjadi. 
Cara seseorang memandang suatu situasi yang ambigu dan mengatur informasi yang tersedia adalah pendekatan untuk mencerminkan toleransi ambiguitasnya. Seseorang yang memiliki toleransi ambiguitas yang tinggi adalah seseorang yang menghadapi situasi ambigu yang menantang dan yang berusaha mengatasi situasi yang tidak stabil serta tidak dapat diprediksi agar dapat bekerja dengan baik.

Budner (dalam Furnham dan Marks, 2013) mendefinisikan tolerance for ambiguity sebagai kecenderungan untuk menganggap situasi ambigu sebagai hal yang diinginkan. Fenkel dan Brunswick 1949, 1951 ( dalam Furnham dan Marks, 2013) berpendapat bahwa tolerance for ambiguity menyamaratakan berbagai aspek fungsi emosional dan kognitif individu, gaya karakterisasi kognitif, sistem kepercayaan dan sikap, fungsi interpersonal dan sosial, dan perilaku dalam memecahkan masalah.

Menurut (Kusmintarti et al. 2014) tolerance for ambiguity adalah karakteristik yang penting bagi seseorang yang akan memutuskan untuk menjadikan kewirausahaan sebagai pilihan karier karena tantangan dan potensi sukses di sebuah bisnis yang baru tidak dapat diprediksi.

\section{Indikator Tolerance for Ambiguity}

Menurut Kusmintarti et al. (2014), indikator tolerance for ambiguity mencakup (1) menyesuaikan dengan momen yang tidak terduga (2) mempertimbangkan informasi baru (3) kesadaran akan kemungkinan rencana yang tidak terkendali, (4) mengumpulkan dan mengelola informasi.

\section{2) Dimensi Internal Locus of Control}

Menurut Rotter (1966), Locus of control merupakan salah satu variable kepribadian (personality), yang didefinisikan sebagai keyakinan individu terhadap mampu tidaknya mengontrol nasib (destiny) sendiri. Robin dan Judge (dalam Murni, 2017 : 7) menjelaskan locus of control merupakan tingkatan dimana individu yakin bahwa mereka adalah penentu nasib mereka sendiri. Gibson (dalam Murni, 2017: 7) mengatakan bahwa locus of control merupakan karakteristik kepribadian yang menguraikan orang yang menganggap bahwa kendali kehidupan mereka datang dari dalam diri mereka 
sendiri sebagai internalizers. Sedangkan orang yang yakin bahwa kehidupan mereka dikendalikan oleh faktor eksternal disebut externalizer. Rotter (dalam Brannon dan Feist 2009 dan dalam Murni, 2017 : 8) berpandangan bahwa individu yang percaya bahwa mereka mengendalikan hidup mereka sendiri adalah individu yang memiliki internal locus of control. Dayaksisni dan Yuniardi (dalam Murni, 2017: 8) mengatakan bahwa individu dengan internal locus of control melihat independency yang besar dalam kehidupan dengan kata lain hidupnya sangat ditentukan oleh dirinya sendiri.

Sarafino dan Tomothy (dalam Murni, 2017 : 8) mengemukakan bahwa individu dengan internal locus of control yakin bahwa kesuksesan dan kegagalan yang terjadi dalam hidup tergantung pada diri sendiri. Orang yang mempunyai internal locus of control mempunyai keyakinan bahwa apa yang terjadi pada dirinya, kegagalan - kegagalan, keberhasilan-keberhasilannya karena pengaruh dirinya sendiri. Menurut Petri (dalam Dewi : 13) locus of control merupakan dimensi kepribadian yang berupa kontinum dari internal menuju eksternal. Kedua tipe locus of control terdapat pada setiap individu, hanya saja ada kecenderungan untuk memiliki salah satu tipe tertentu. Selain itu locus of control tidak bersifat statis tetapi juga dapat berubah. Hal tersebut disebabkan karena situasi dan kondisi yang menyertainya.

\section{Indikator Internal Locus of Control}

Menurut Kusmintarti et al. 2014 indikator internal locus of control mencakup : (1) bekerja keras untuk mencapai tujuan (2) bekerja keras untuk meraih sukses dalam hidup (3) percaya bahwa jika tidak bekerja keras maka akan menyebabkan kegagalan (4) bekerja keras untuk meraih prestasi.

\section{3) Dimensi Propensity to Take a Risk}

Propensity to take a risk didefinisikan oleh Kuip dan Verheul (dalam Bux dan Honglin, 2015) sebagai penerimaan risiko ketika terlibat dalam suatu kegiatan dan karenanya probabilitas keberhasilan setiap kegiatan kurang dari 100\%. Menurut Lowe dan Marriott (dalam Kusmintarti et al. 2014) Pengusaha bersedia untuk mengambil risiko terhadap saat-saat yang tidak pasti tetapi 
mereka mengharapkan manfaat sebagai imbalan dari menanggung ketidakpastian.Menurut Zimmerer et al. 2008 (dalam Kusmintarti et al. 2014) pengusaha bukan orang yang siap mengambil risiko tanpa perhitungan apapun, tetapi mereka adalah orang yang mengambil risiko berdasarkan perhitungan.

Pada penelitiannya Kusmintarti et al. 2014 mendefinisikan kecenderungan risiko sebagai kecenderungan yang tidak takut untuk mengambil risiko tetapi tidak pada tingkat yang sangat rendah maupun sebagai pengambil risiko pada tingkat yang terlalu tinggi. Menurut Koh (1996) seseorang yang memiliki kecenderungan mengambil risiko dapat didefinisikan sebagai seseorang yang memiliki orientasi dalam mengambil peluang dalam konteks pengambilan keputusan yang tidak pasti.

Darmanto (2012) mengatakan bahwa dalam beberapa penelitian menunjukkan adanya peran dari kebutuhan berprestasi ( need for achievement), locus of control, dan kecenderungan mengambil risiko (risk propensity) sebagai sifat-sifat personalitas (personality traits) yang mendorong intensi (minat) berwirausaha (Kristiansen dan Indarti, 2004 ; Ramayah dan Harun, 2005 ; Taormina dan Lao, 2006).

\section{Indikator Propensity to Take a Risk}

Menurut Kusmintarti et al. 2014 indikator propensity to take a risk mencakup : (1) menghitung keuntungan dan kerugian dalam pengambilan keputusan (2) bersedia untuk mengambil risiko sebagai akibat dari keputusan yang dibuat (3) bersedia untuk mengambil risiko sebagai akibat dari apa yang dilakukan (4) bersedia mengambil risiko berdasarkan tingkat pencapaian.

\section{4) Dimensi Creativity}

Menurut Zimmerer et al. (dalam Kusmintarti, et al. 2014) kreativitas didefinisikan sebagai kemampuan untuk mengembangkan ide - ide baru dan untuk menemukan cara-cara baru dalam melihat masalah dan peluang. Kusmintarti et al. (2014) mengemukakan kreativitas adalah proses pengembangan respon asli, baru dan akurat untuk suatu masalah. Respon asli didefinisikan sebagai sesuatu yang belum ada sebelumnya. Birdthisle (dalam Kusmintarti et al. 2014) mengemukakan kreativitas adalah karakteristik penting 
yang harus dimiliki oleh seorang yang memutuskan untuk memilih kewirausahaan sebagai pilihan kariernya.

\section{Indikator Creativity}

Menurut Kusmintarti et al. (2014) indikator creativity mencakup : (1) mengembangkan cara lain (2) mengembangkan pandangan yang berbeda (3) mengembangkan ide-ide baru (4) mengembangkan alternatif untuk memecahkan masalah

\section{Sikap Kewirausahaan}

Ajzen (dalam Kusmintarti et al. 2014) mendefinisikan attitude atau sikap sebagai kecenderungan untuk bereaksi positif atau negatif kepada sebuah objek, orang, institusi atau waktu. Kusmintarti et al. (2014) mendefinisikan sikap kewirausahaan sebagai kecenderungan untuk bereaksi positif atau negatif terhadap kewirausahaan

\section{Indikator Sikap Kewirausahaan}

Menurut Kusmintarti et al. (2014) indikator sikap kewirausahaan mencakup (1) motivasi menjadi bos dari bisnisnya sendiri (2) motivasi bekerja pada jadwal kerja yang fleksibel (3) motivasi untuk menghadiri kegiatan kewirausahaan (4) bersedia bekerja keras untuk memulai bisnis baru

\section{Pengaruh Karakteristik Psikologi terhadap Intensi kewirausahaan Dimediasi Sikap Kewirausahaan}

Rush dan Ferse (dalam Sharaf et al. 2018) menyatakan bahwa locus of control, propensity to take risk, self-efficacy, need for achievement, tolerance for ambiguity dan inovasi adalah karakteristik psikologi yang terkait dengan kewirausahaan yang akan memprediksi sikap kewirausahaan. Baron dan Kenny (dalam Kusmintarti et al. 2014) menyatakan bahwa sikap kewirausahaan bertindak sebagai penguat karakteristik kewirausahaan yang memengaruhi niat kewirausahaan. 


\section{Metode Penelitian}

Penelitian ini merupakan penelitian asosiatif untuk mengetahui hubungan antara dua variabel atau lebih. Dengan penelitian ini, dapat dibangun suatu teori yang dapat berfungsi menjelaskan, meramalkan, dan mengontrol suatu gejala. Penelitian ini menggunakan metode penelitian survey untuk mendapatkan data pada masa lampau atau saat ini, tentang keyakinan, pendapat, karakteristik, perilaku, hubungan variable, dan untuk menguji beberapa hipotesis tentang variable sosiologis dan psikologis dari sampel yang diambil dari populasi tertentu, dengan cara mengumpulkan informasi melalui kuesinoner yang dibagikan kepada mahasiswa lima universitas di Yogyakarta. Sifat penelitian ini adalah kuantitatif di mana data berupa angka-angka dan dianalisis menggunakan statistik.

Penelitian ini dilakukan pada bulan Desember tahun 2019 dan Februari tahun 2020 di Universitas Gadjah Mada, Universitas Islam Negeri Sunan Kalijaga, Universitas Sanata Dharma, Universitas Atma Jaya Yogyakarta, dan Universitas Sarjanawiyata Tamansiswa. Populasi penelitian ini adalah seluruh mahasiswa lima universitas di Yogyakarta, berdasarkan jenis perguruan tinggi dengan kategori universitas berbasis negeri dan swasta agama maupun non-agama, yaitu UGM, UIN Sunan Kalijaga, USD, UAJY, dan UST. Sampel dalam penelitian ini adalah sebagian mahasiswa UGM, UIN Sunan Kalijaga, USD, UAJY, dan UST. Jumlah sampel ditentukan dengan menggunakan kalkulator statistik online dengan tingkat kepercayaan $95 \%$ dan tingkat error sebesar $10 \%$. Pendistribusian sampel dilakukan berdasarkan pada proporsi jumlah mahasiswa di setiap universitas, dengan perhitungan sebagai berikut:

Tabel 1

Pendistribusian Sampel

\begin{tabular}{clccc}
\hline \multirow{2}{*}{ No } & \multicolumn{1}{c}{ Nama Universitas } & $\begin{array}{c}\text { Jumlah Mahasiswa } \\
\mathbf{2 0 1 9 / 2 0}(\mathbf{Y})\end{array}$ & $\begin{array}{c}\text { TA } \\
(\mathbf{Z})\end{array}$ & $\begin{array}{c}\text { Proporsi } \\
\mathbf{1 0 0})\end{array}$ \\
\hline 1 & Universitas Gadjah Mada & 56.263 & 0,49 & 49 \\
\hline 2 & $\begin{array}{l}\text { Universitas Islam Negeri } \\
\text { Sunan Kalijaga }\end{array}$ & 20.577 & 0,18 & 18 \\
\hline 3 & Universitas Sanata Dharma & 12.741 & 0,11 & 11 \\
\hline 4 & $\begin{array}{l}\text { Universitas Atmajaya } \\
\text { Yogyakarta }\end{array}$ & 12.399 & 0,11 & 11 \\
\hline 5 & $\begin{array}{l}\text { Universitas Sarjana Wiyata } \\
\text { Tamansiswa }\end{array}$ & 12.245 & 0,11 & 11 \\
\hline & Jumlah & 114.255 & 1,00 & 100 \\
\hline
\end{tabular}

Sumber: https://forlap.ristekdikti.go.id/perguruantinggi/search 
Teknik pengambilan sampel yang digunakan pada penelitian ini adalah non probability sampling, yaitu sampling insidental. Sumber dan jenis data dalam penelitian ini adalah data primer dan data sekunder. Data primer pada penelitian ini berupa jawaban dari hasil penyebaran kuesioner kepada mahasiswa UGM, UIN Sunan Kalijaga, USD, UAJY dan UST mengenai karakteristik psikologi, sikap kewirausahaan dan intensi kewirausahaan. Sedangkan data sekunder dalam penelitian ini adalah data yang diperoleh peneliti secara tidak langsung dan diperoleh dari jurnal-jurnal, buku-buku, penelitian terdahulu serta internet.

Pada penelitian ini teknik pengumpulan data dilakukan dengan membagikan kuesioner kepada responden. Teknik ini dilakukan dengan memberikan daftar pertanyaan tertulis kepada sampel responden yang dipilih dari populasi. Kuesioner yang dibagikan kepada responden akan dibagi menjadi beberapa bagian:

1. Bagian pertama berisi beberapa pertanyaan konfirmasi

2. Bagian kedua berisi beberapa pertanyaan mengenai identitas atau profil responden

3. Bagian ketiga berisi petunjuk pengisian kuesioner

4. Bagian keempat yaitu pengisian kuesioner yang dibagi menjadi karakteristik psikologi; sikap kewirausahaan; dan intensi kewirausahaan

Terdapat dua macam jenis analisis statistik yang digunakan untuk analisis data dalam penelitian ini yakni : (1) statistik deskriptif dan (2) statistik inferensial. Dalam teknis analisis statistic deskriptif akan dipaparkan analisis deskriptif responden dan analisis deskriptif variabel. Sedangkan teknik analisis statistic inferensial yang digunakan adalah analisis jalur (path analysis). Streiner (dalam Aurellia, 2019) menyatakan bahwa analisis jalur merupakan perluasan dari regresi linier berganda, dan yang memungkinkan analisis model-model yang lebih kompleks. Analisis jalur dilakukan jika terdapat suatu variabel mediasi, yaitu variabel yang bersifat perantara (jembatan) dari variabel independen ke variabel dependen. Langkah-langkah analisis jalur (path analysis) adalah sebagai berikut:

\section{Menyusun Hipotesis}

$\mathrm{Ha}$ : Ada pengaruh antara karakteristik psikologi terhadap intensi kewirausahaan dimediasi sikap kewirausahaan.

H0 : tidak ada pengaruh antara karakteristik psikologi terhadap intensi 
kewirausahaan dimediasi sikap kewirausahaan.

2. Pemodelan

Model I : X memengaruhi Z

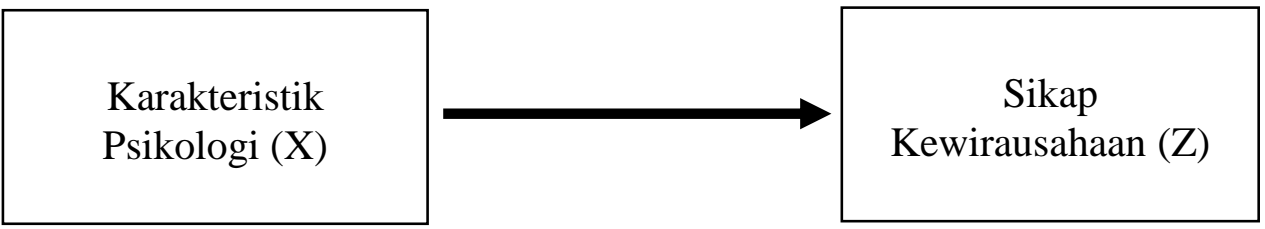

Gambar 1. Persamaan Model I

Persamaan regresi model I : meregresi $Z=\rho_{m x} X+\varepsilon_{1}$

Model II : X memengaruhi Y

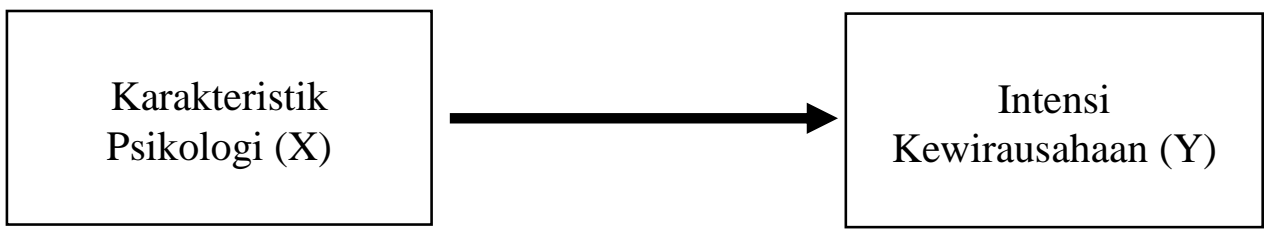

Gambar 2. Persamaan Model II

Persamaan regresi model II : meregresi $\mathrm{Y}=\rho_{m x} X+\varepsilon_{2}$

Model I : X, Z memengaruhi Y

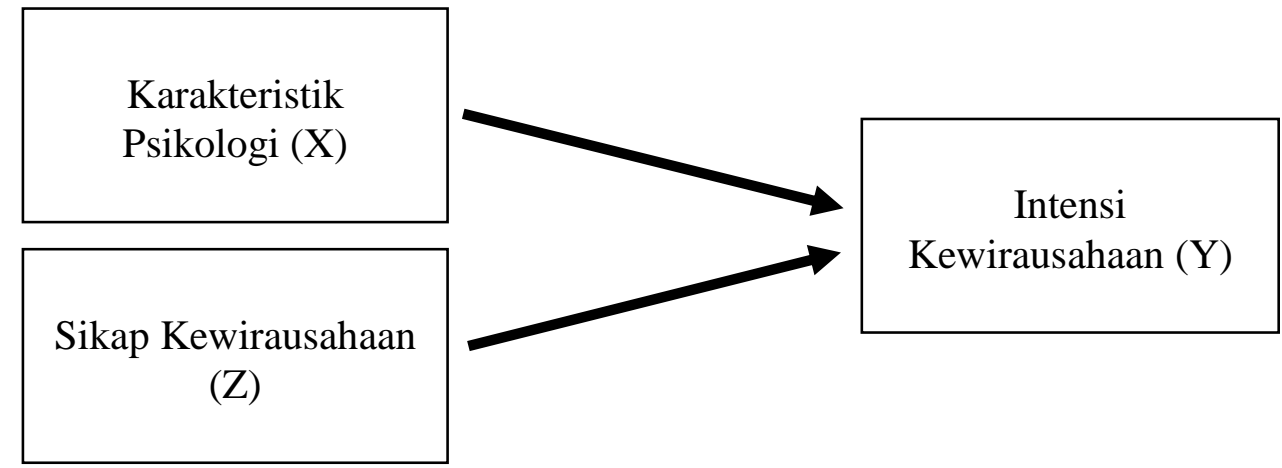

Gambar 3. Persamaan Model III

Persamaan regresi model III : meregresi $\mathrm{Y}=\rho_{m x} X+\rho_{m x} \mathrm{Z}+\varepsilon_{3}$

3. Uji asumsi klasik

1) Uji Normalitas

Menurut Ghozali (dalam Aurellia, 2019) uji normalitas bertujuan untuk menguji apakah dalam model regresi, variabel pengganggu atau residual memiliki distribusi normal. Adapun pedoman yang dapat digunakan untuk dapat mengetahui residual berdistribusi normal atau tidak dengan melihat 
pada nilai signifikansi pada hasil uji Kolmogorov - Smirnov, yaitu sebagai berikut:

a) Jika nilai Sig $\geq 0,05$ maka data distribusi normal

b) Jika nilai Sig < 0,05 maka datatidak normal.

2) Uji Linearitas

Uji linearitas digunakan untuk melihat apakah model yang dibangun mempunyai hubungan linear atau tidak. Uji linearitas digunakan untuk mengkonfirmasi apakah sifat linear antara dua variabel yang diidentifikasikan secara teori sesuai atau tidak dengan hasil observasi yang ada. Uji linearitas menggunakan program SPSS, dengan asumsi :

a) Jika pada output signifikansi pada ANOVA Table > dari 0,05 maka ada hubungan linear secara signifikan antar variabel

3) Uji Heteroskedastisitas

Menurut Ghozali (dalam Aurellia, 2019) uji heteroskedastisitas bertujuan untuk menguji apakah dalam model regresi terjadi ketidaksamaan varians dari residual satu pengamatan ke pengamatan lainnya. Jika varians residual dari satu pengamatan ke pengamatan lainnya tetap maka disebut homoskedastisitas, dan jika berbeda maka terjadi heteroskedastisitas. Pengujian untuk melihat adanya gejala heteroskedastisitas dilakukan dengan uji Glejser. Dasar pengambilan keputusan pada uji Glejser adalah sebagai berikut:

a) Jika nilai $\operatorname{Sig} \geq 0,05$ maka tidak terjadi heteroskedastisitas.

b) Jika nilai Sig < 0,05 maka terjadi heteroskedastisitas.

4. Uji Hipotesis

1) Meregresi model I, model II dan model III untuk mendapatkan koefisien dan signifikansi

2) Keputusan

a. Bila variabel independen $(\mathrm{X})$ berpengaruh signifikan terhadap variabel mediasi $(\mathrm{Z})$; serta koefisien variabel independen $(\mathrm{X})$ dan variabel dependen (Y) sebelum dan sesudah memasukkan variabel mediasi (Z) tidak berubah dan tetap signifikan maka $\mathrm{H}_{0}$ diterima dan $\mathrm{H}_{\mathrm{a}}$ ditolak. 
b. Bila variabel independen $(\mathrm{X})$ berpengaruh signifikan terhadap variabel mediasi $(\mathrm{Z})$; serta koefisien variabel independen $(\mathrm{X})$ dan variabel dependen (Y) sebelum dan sesudah memasukkan variabel mediasi (Z) nilai koefisien turun maka $\mathrm{H}_{0}$ ditolak dan $\mathrm{H}_{\mathrm{a}}$ diterima

5. Menentukan Jenis Mediasi

Penentuan jenis mediasi dilakukan apabila $\mathrm{H}_{\mathrm{a}}$ diterima. Mediasi menunjukan bagaimana sebuah variabel independen $(\mathrm{X})$ memengaruhi variabel dependen $(\mathrm{Y})$ melalui satu atau lebih variabel intervening yang dinamakan dengan variabel mediator (M). Selanjutnya berikut adalah kriteria sebuah variabel mediasi menjadi variabel mediasi penuh atau variabel mediasi parsial :

1) Mediasi penuh apabila koefisien variabel independen (X) terhadap variabel dependen (Y) sebelum dan sesudah memasukan variabel mediasi (Z) nilainya turun dan tidak signifikan.

2) Mediasi parsial apabila koefisien variabel independen (X) terhadap variabel dependen (Y) sebelum dan sesudah memasukan variabel mediasi (Z) nilainya turun dan tetap signifikan

6. Menentukan Pengaruh Langsung dan Tidak langsung

Langkah menentukan pengaruh langsung dan tidak langsung dilakukan apabila jenis mediasi adalah mediasi parsial.

1) Menghitung nilai pengaruh langsung

Pengaruh langsung diperoleh dengan cara mengkuadratkan B Standardized dan dikali $100 \%$ jika ingin diperoleh \% langsung.

2) Menghitung nilai pengaruh tidak langsung

Pengaruh tidak langsung diperoleh dengan cara mengkalikan B Standardized variabel $\mathrm{X}$ dengan korelasi antar variabel $\mathrm{X}$ dan $\mathrm{Z}$ dikalikan dengan B Standardized variabel Z.

3) Menghitung nilai pengaruh total

Pengaruh total variabel terhadap variabel $\mathrm{Y}$ adalah dengan menjumlahkan seluruh pengaruh langsung dan tidak langsung yang sudah diperoleh.

4) Merekapitulasi dalam tabel: 


\section{Hasil dan Pembahasan}

\section{Uji Instrumen: Uji Validitas dan Reliabilitas}

Uji Validitas yang digunakan dalam penelitian ini menggunakan teknik korelasi product moment pearson. Dikatakan valid apabila hasil uji didapatkan $\mathrm{r}_{\text {hitung }} \geq \mathrm{r}_{\text {tabel. }}$. Untuk responden dengan jumlah 100 orang dan nilai alpha 5\% maka rtabel sebesar 0,1986. Selanjutnya nilai rtabel tersebut digunakan sebagai kriteria validitas item - item yang ada dalam kuesioner. Suatu item dapat dinyatakan valid apabila memiliki koefisien korelasi $r_{\text {hitung }}$ total lebih besar dari pada 0,1986 . Berikut adalah hasil uji validitas pada masing - masing variabel:

Tabel 2

\section{Rangkuman Tes Validitas Sikap Kewirausahaan}

\begin{tabular}{cccl}
\hline Pernyataan & Koefisien Korelasi (rhitung) & rtabel & Keterangan \\
\hline SK1 & 0,700 & 0,1986 & Valid \\
SK2 & 0,688 & 0,1986 & Valid \\
SK3 & 0,673 & 0,1986 & Valid \\
SK4 & 0,751 & 0,1986 & Valid \\
\hline
\end{tabular}

Sumber : Data primer, diolah 2020

Tabel 3

Rangkuman Tes Validitas Sikap Kewirausahaan

\begin{tabular}{cccl}
\hline Pernyataan & Koefisien Korelasi (rhitung) & rtabel & Keterangan \\
\hline IK1 & 0,824 & 0,1986 & Valid \\
IK2 & 0,84 & 0,1986 & Valid \\
IK3 & 0,797 & 0,1986 & Valid \\
IK4 & 0,485 & 0,1986 & Valid \\
IK5 & 0,661 & 0,1986 & Valid \\
\hline
\end{tabular}

Sumber : Data primer, diolah 2020 
Tabel 4

Rangkuman Tes Validitas Karakteristik Psikologi

\begin{tabular}{cccl}
\hline Pernyataan & Koefisien Korelasi (rhitung) & rtabel & Keterangan \\
\hline T1 & 0,339 & 0,1986 & Valid \\
T2 & 0,345 & 0,1986 & Valid \\
T3 & 0,382 & 0,1986 & Valid \\
T4 & 0,485 & 0,1986 & Valid \\
I1 & 0,400 & 0,1986 & Valid \\
I2 & 0,451 & 0,1986 & Valid \\
I3 & 0,509 & 0,1986 & Valid \\
I4 & 0,531 & 0,1986 & Valid \\
P1 & 0,612 & 0,1986 & Valid \\
P2 & 0,427 & 0,1986 & Valid \\
P3 & 0,476 & 0,1986 & Valid \\
P4 & 0,596 & 0,1986 & Valid \\
C1 & 0,538 & 0,1986 & Valid \\
C2 & 0,441 & 0,1986 & Valid \\
C3 & 0,551 & 0,1986 & Valid \\
C4 & 0,516 & 0,1986 & Valid \\
\hline
\end{tabular}

Sumber : Data primer, diolah 2020

Berdasarkan tabel 2, 3, dan 4 dapat disimpulkan bahwa seluruh butir pernyataan pada indikator variabel mempunyai nilai $r_{\text {hitung }}>r_{\text {tabel }}$ sehingga seluruh butir pernyataan dikatakan valid.

Reliabilitas menunjukkan bahwa suatu instrumen cukup dapat dipercaya untuk digunakan sebagai alat pengumpul data dengan kata lain reliabilitas menguji kehandalan suatu instrumen. Suatu instrumen dapat dikatakan handal (reliable) bila memiliki koefisien kehandalan atau alpha sebesar 0,6 atau lebih. Arikunto (dalam Aurellia, 2019). Uji reliabilitas pada penelitian ini menggunakan teknik Cronbach's Alpha. Sehingga apabila nilai reliabilitas / alpha $\geq 0,60$ maka instrumen yang digunakan dalam penelitian ini dapat dinyatakan reliabel. Berikut adalah hasil analisis reliabilitas instrumen pada masing-masing variabel: 
Tabel 5

Hasil Uji Reliabilitas

\begin{tabular}{lccl}
\hline \multicolumn{1}{c}{ Variabel } & Cronbach's Alpha & N of Items & Keterangan \\
\hline Karakteristik Psikologi & 0,773 & 16 & Reliabel \\
\hline Sikap Kewirausahaan & 0,649 & 4 & Reliabel \\
\hline Intensi Kewirausahaan & 0,774 & 5 & Reliabel \\
\hline
\end{tabular}

Sumber : Data primer, diolah 2020

Berdasarkan data dari tabel 5 di atas, dapat disimpulkan bahwa variabel karakteristik psikologi, sikap kewirausahaan dan intensi kewirausahaan memiliki nilai yang memenuhi syarat sehingga dapat dinyatakan bahwa alat ukur tersebut reliabel karena nilai Cronbach's Alpha lebih dari 0,60.

\section{Deskripsi responden}

Analisis ini digunakan untuk memperoleh gambaran dengan cara mengelompokkan responden berdasarkan pada karakteristik tertentu. Selanjutnya akan dilakukan pengolahan data melalui perhitungan statistik deskriptif. Analisis deskriptif responden dikelompokkan sebagai berikut:

1. Berdasar jenjang pendidikan: dari 98 responden yang dijadikan sampel dalam penelitian ini, 96 orang merupakan mahasiswa yang menempuh jenjang pendidikan S1 dan 2 orang menempuh jenjang pendidikan S2 / profesi

2. Berdasar Fakultas: dari 98 responden yang dijadikan sampel dalam penelitian ini, 26 orang merupakan mahasiswa dari fakultas ekonomi, dan 72 orang merupakan mahasiswa dari fakultas non-ekonomi

3. Berdasar bidang ilmu: dari 98 responden yang dijadikan sampel dalam penelitian ini, paling banyak berasal dari mahasiswa yang menempuh bidang ilmu eksakta / teknik yakni sebesar 60. Sedangkan mahasiswa yang menempuh pendidikan di bidang ilmu sosial sebanyak 38 orang.

4. Berdasar tahun masuk: dari 98 responden yang dijadikan sampel dalam penelitian ini paling banyak berasal dari mahasiswa angkatan 17 dan 19 yakni sebanyak 31 orang. Terbanyak kedua berasal dari responden dengan tahun masuk perguruan tinggi / angkatan 18 yakni sebanyak 19. Terbanyak ketiga merupakan responden 
dengan tahun masuk perguruan tinggi / angkatan 16 sebanyak 13. Selanjutnya diurutan keempat merupakan responden dengan tahun masuk perguruan tinggi / angkatan 15 sebanyak 3 orang. Diurutan terakhir merupakan responden dengan tahun masuk perguruan tinggi / angkatan lainnya, dimana angkatan responden tersebut diluar angkatan 19,18,17,16 maupun 15 sebanyak 1 orang.

5. Berdasar jenis kelamin: dari 98 responden yang dijadikan sampel dalam penelitian ini paling banyak merupakan responden dengan jenis kelamin laki - laki, yakni sebanyak 60 orang responden. Untuk responden perempuan dalam penelitian ini sebanyak 38 orang.

\section{Deskripsi Variabel}

Analisis deskriptif variabel pada penelitian ini digunakan untuk mendapatkan gambaran mengenai variabel mean. Dengan interval 0,75 , berikut adalah rentang skor analisis deskriptif pada masing - masing variabel dalam penelitian ini:

Tabel 6

Rentang Skor Analisis Deskriptif

\begin{tabular}{|c|c|c|c|}
\hline Rentang & $\begin{array}{c}\text { Karakteristik } \\
\text { Psikologi }\end{array}$ & $\begin{array}{c}\text { Sikap } \\
\text { Kewirausahaan } \\
\text { Sangat Rendah }\end{array}$ & $\begin{array}{c}\text { Intensi } \\
\text { Kewirausahaan }\end{array}$ \\
\hline $1,00-1,75$ & Sangat Rendah & Sangat Rendah \\
\hline $1,76-2,50$ & Rendah & Rendah & Rendah \\
\hline $2,51-3,25$ & Tinggi & Tinggi & Tinggi \\
\hline $3,26-4,00$ & Sangat Tinggi & Sangat Tinggi & Sangat Tinggi \\
\hline
\end{tabular}


Sedangkan analisis deskripsi variabel adalah sebagai berikut:

Tabel 7

Hasil Analisis Deskriptif Variabel Karakteristik Psikologi

\begin{tabular}{|c|c|c|c|c|}
\hline Dimensi & Mean & Indikator & Mean & Kategori \\
\hline \multirow{4}{*}{$\begin{array}{l}\text { Tolerance } \\
\quad \text { for } \\
\text { Ambiguity }\end{array}$} & \multirow{4}{*}{3,12} & $\begin{array}{l}\text { Menyesuaikan diri dengan momen } \\
\text { yang tidak terduga }\end{array}$ & 3,05 & Tinggi \\
\hline & & $\begin{array}{l}\text { Mempertimbangkan informasi } \\
\text { baru }\end{array}$ & 3,37 & Sangat Tinggi \\
\hline & & $\begin{array}{l}\text { Kesadaran akan kemungkinan } \\
\text { rencana yang tidak terkendali }\end{array}$ & 3,10 & Tinggi \\
\hline & & $\begin{array}{l}\text { Mengumpulkan dan mengelola } \\
\text { informasi }\end{array}$ & 3,09 & Tinggi \\
\hline \multirow{4}{*}{$\begin{array}{l}\text { Internal } \\
\text { Locus of } \\
\text { Control }\end{array}$} & \multirow{4}{*}{3,36} & $\begin{array}{l}\text { Bekerja keras untuk mencapai } \\
\text { tujuan }\end{array}$ & 3,47 & Sangat Tinggi \\
\hline & & $\begin{array}{l}\text { Bekerja keras untuk meraih sukses } \\
\text { dalam hidup }\end{array}$ & 3,53 & Sangat Tinggi \\
\hline & & $\begin{array}{l}\text { Percaya bahwa jika tidak bekerja } \\
\text { keras maka akan menyebabkan } \\
\text { kegagalan }\end{array}$ & 3,20 & Tinggi \\
\hline & & $\begin{array}{l}\text { Bekerja keras untuk meraih } \\
\text { prestasi }\end{array}$ & 3,23 & Tinggi \\
\hline \multirow{4}{*}{$\begin{array}{l}\text { Propensity to } \\
\text { Take a Risk }\end{array}$} & \multirow{4}{*}{3,26} & $\begin{array}{l}\text { Menghitung keuntungan dalam } \\
\text { pengambilan keputusan }\end{array}$ & 3,19 & Tinggi \\
\hline & & $\begin{array}{l}\text { Bersedia untuk mengambil risiko } \\
\text { sebagai akibat dari keputusan yang } \\
\text { dibuat }\end{array}$ & 3,41 & Sangat Tinggi \\
\hline & & $\begin{array}{l}\text { Bersedia untuk mengambil risiko } \\
\text { sebagai akibat dari apa yang } \\
\text { dilakukan }\end{array}$ & 3,39 & Sangat Tinggi \\
\hline & & $\begin{array}{l}\text { Bersedia mengambil risiko } \\
\text { berdasarkan tingkat pencapaian }\end{array}$ & 3,04 & Tinggi \\
\hline \multirow{5}{*}{ Creativity } & \multirow{5}{*}{3,16} & Mengembangkan cara lain & 3,16 & Tinggi \\
\hline & & $\begin{array}{l}\text { Mengembangkan pandangan yang } \\
\text { berbeda }\end{array}$ & 3,14 & Tinggi \\
\hline & & Mengembangkan ide-ide bar & 3,14 & Tinggi \\
\hline & & $\begin{array}{l}\text { Mengembangkan alternatif untuk } \\
\text { memecahkan masalah }\end{array}$ & 3,20 & Tinggi \\
\hline & & Mean & 3,22 & Tinggi \\
\hline
\end{tabular}

Sumber: Data primer, diolah 2020

Dari tabel 7 di atas, dapat diketahui bahwa rata-rata jawaban responden terhadap karakteristik psikologi yang diasosiasikan dengan kewirausahaan pada penelitian ini adalah 3,22. Berdasarkan pada rentang skor analisis, 3,22 menunjukkan bahwa mahasiswa pada umumnya memiliki karakteristik psikologi yang 
diasosiasikan dengan kewirausahaan adalah tinggi.

Tabel 8

Hasil Analisis Deskriptif

Variabel Sikap Kewirausahaan

\begin{tabular}{|l|c|l|}
\hline \multicolumn{1}{|c|}{ Indikator } & Mean & \multicolumn{1}{|c|}{ Kategori } \\
\hline $\begin{array}{l}\text { Motivasi menjadi bos dari bisnisnya } \\
\text { sendiri }\end{array}$ & 3,34 & Sangat Tinggi \\
\hline $\begin{array}{l}\text { Motivasi bekerja pada jadwal kerja } \\
\text { yang fleksibel }\end{array}$ & 3,42 & Sangat Tinggi \\
\hline $\begin{array}{l}\text { Motivasi untuk menghadiri kegiatan } \\
\text { kewirausahaan }\end{array}$ & 2,99 & Tinggi \\
\hline $\begin{array}{l}\text { Bersedia bekerja keras untuk memulai } \\
\text { bisnis baru }\end{array}$ & 3,29 & Sangat Tinggi \\
\hline \multicolumn{1}{|c|}{ Mean } & $\mathbf{3 , 2 6}$ & Sangat Tinggi \\
\hline
\end{tabular}

Sumber: Data primer, diolah 2020

Dari tabel 8 di atas, dapat diketahui bahwa rata-rata jawaban responden terhadap sikap kewirausahaan pada penelitian ini adalah 3,26. Berdasarkan rentang skor analisis, 3,26 menunjukkan bahwa pada umumnya mahasiswa di lima universitas Yogyakarta memiliki sikap kewirausahaan yang sangat tinggi.

Tabel 9

Hasil Analisis Deskriptif Variabel Intensi Kewirausahaan

\begin{tabular}{|l|c|l|}
\hline \multicolumn{1}{|c|}{ Indikator } & Mean & \multicolumn{1}{c|}{ Kategori } \\
\hline $\begin{array}{l}\text { Motivasi untuk membangun bisnis } \\
\text { setelah lulus }\end{array}$ & 3,22 & Tinggi \\
\hline $\begin{array}{l}\text { Motivasi untuk membangun bisnis di } \\
\text { masa depan }\end{array}$ & 3,27 & Sangat Tinggi \\
\hline Motivasi untuk merealisasikan bisnis & 3,35 & Sangat Tinggi \\
\hline $\begin{array}{l}\text { Motivasi membangun bisnis setelah } \\
\text { memiliki modal finansial }\end{array}$ & 3,24 & Tinggi \\
\hline $\begin{array}{l}\text { Motivasi untuk membangun bisnis } \\
\text { berdasarkan jejaring sosial }\end{array}$ & 3,20 & Tinggi \\
\hline \multicolumn{1}{|c|}{ Mean } & $\mathbf{3 , 2 6}$ & Sangat Tinggi \\
\hline
\end{tabular}

Sumber: Data primer, diolah 2020

Dari tabel 9 di atas, dapat diketahui bahwa rata - rata jawaban responden terhadap intensi kewirausahaan pada penelitian ini adalah 3,26. Berdasarkan rentang skor analisis, 3,26 menunjukkan bahwa pada umumnya mahasiswa di lima universitas Yogyakarta memiliki intensi terhadap kewirausahaan yang sangat tinggi. 


\section{Uji Asumsi Klasik}

Uji asumsi klasik yang digunakan dalam penelitian ini adalah uji normalitas, uji linearitas, dan uji heteroskedastisitas. Uji normalitas bertujuan untuk menguji apakah dalam model regresi, variabel pengganggu atau residual memiliki distribusi normal. Adapun pedoman yang dapat digunakan untuk dapat mengetahui residual berdistribusi normal atau tidak dengan melihat pada nilai signifikansi padahasil uji Kolmogorov-Smirnov, apabila nilai Sig $\geq 0,05$ maka data berdistribusi normal. Jika nilai Sig $<0,05$ maka data tidak normal. Berdasarkan hasil pengujian dengan menggunakan SPSS 22.0 for windows dapat diketahui bahwa nilai signifikansi untuk sebesar 0,168>0,05. Angka tersebut menunjukkan bahwa nilai residual berdistribusi normal. Sehingga peneliti dapat melakukan analisis lebih lanjut pada penelitian ini.

\section{Tabel 10}

Hasil Uji Normalitas

One-Sample Kolmogorov-Smirnov Test

\begin{tabular}{llr} 
& & $\begin{array}{r}\text { Unstandardized } \\
\text { Residua }\end{array}$ \\
\hline $\mathrm{N}$ & Mean & 98 \\
Normal Parameters & a,b &, 0000000 \\
& Std. Deviation &, 36230419 \\
Most Extreme Differences & Absolute &, 077 \\
& Positive &, 062 \\
& Negative &,- 077 \\
Test Statistic & &, 077 \\
\hline Asymp. Sig. (2-tailed) & &, $168^{\circ}$ \\
\hline
\end{tabular}

a. Test distribution is Normal.

b. Calculated from data.

c. Lilliefors Significance Correction.

Sumber: Data primer diolah, 2020

Uji linearitas digunakan untuk melihat apakah model yang dibangun mempunyai hubungan linear atau tidak. Uji linearitas digunakan untuk mengkonfirmasi apakah sifat linear antara dua variabel yang diidentifikasikan secara teori sesuai atau tidak dengan hasil observasi yang ada. Uji linearitas menggunakan program SPSS, dengan asumsi jika pada output signifikansi pada ANOVA Table > dari 0,05 maka ada hubungan linear secara signifikan antar variabel. Dari hasil pengujian dengan menggunakan program SPSS 22.0 for windows dapat diketahui bahwa: 
1. nilai signifikansi deviation from linearity antar variabel karakteristik psikologi (X) dan variabel intensi kewirausahaan (Y) sebesar $831>0,05$. Angka tersebut menunjukkan bahwa terdapat hubungan linear secara signifikan antara variabel karakteristik psikologi dengan variabel intensi kewirausahaan (Y) pada penelitian ini.

2. nilai signifikansi deviation from linearity antar variabel sikap kewirausahaan (Z) dan variabel intensi kewirausahaan (Y) sebesar 0,360>0,05. Angka tersebut menunjukkan adanya hubungan linear yang signifikan antara variabel sikap kewirausahaan ( $\mathrm{Z}$ ) dan variabel intensi kewirausahaan (Y) pada penelitian ini.

3. nilai signifikansi deviation from linearity antara variabel karakteristik psikologi (X) dan variabel sikap kewirausahaan (Z) sebesar 0,872>0,05. Angka tersebut menunjukkan adanya hubungan linear yang signifikan antara variabel karakteristik psikologi $(\mathrm{X})$ dan variabel sikap kewirausahaan (Z) pada penelitian ini.

\begin{tabular}{|c|c|c|c|c|c|c|c|c|}
\hline \multirow[b]{2}{*}{ Intensi } & \multirow[b]{2}{*}{ Between } & \multicolumn{2}{|c|}{ Sum of Squares } & df & \multicolumn{2}{|c|}{ mean square } & \multicolumn{2}{|r|}{ sig } \\
\hline & & (Combined) & 4,372 & & 19 & ,230 & 1,148 & ,323 \\
\hline \multirow[t]{4}{*}{ * Karakteristik } & & Linearity & 1,960 & & 1 & 1,960 & 9,784 &, 002 \\
\hline & & $\begin{array}{l}\text { Deviation } \\
\text { from Linearity }\end{array}$ & 2,411 & & 18 & ,134 & ,669 & ,831 \\
\hline & Within Groups & & 15,628 & & 78 & ,200 & & \\
\hline & Total & & 20,000 & & 97 & & & \\
\hline Intensi & Between & (Combined) & 7,951 & & 8 & ,994 & 7,341 &, 000 \\
\hline \multirow[t]{4}{*}{ * Sikap } & & Linearity & 6,892 & & 1 & 6,892 & 50,906 & ,000 \\
\hline & & $\begin{array}{l}\text { Deviation } \\
\text { from Linearity }\end{array}$ & 1,059 & & 7 & , 151 & 1,117 & ,360 \\
\hline & Within Groups & & 12,049 & & 89 & ,135 & & \\
\hline & Total & & 20,000 & & 97 & & & \\
\hline Sikap & Between & (Combined) & 4,227 & & 19 & ,222 & 1,096 & ,371 \\
\hline \multirow[t]{4}{*}{ * Karakteristik } & & Linearity & 1,956 & & 1 & 1,956 & 9,639 & ,003 \\
\hline & & $\begin{array}{l}\text { Deviation } \\
\text { from Linearity }\end{array}$ & 2,270 & & 18 & , 126 & 621 & ,872 \\
\hline & Within Groups & & 15,830 & & 78 & ,203 & & \\
\hline & Total & & 20,057 & & 97 & & & \\
\hline
\end{tabular}

Sumber: Data primer diolah, 2020 
Uji heteroskedastisitas bertujuan untuk menguji apakah dalam model regresi terjadi ketidaksamaan varians dari residual satu pengamatan ke pengamatan lainnya. Jika varians residual dari satu pengamatan ke pengamatan lainnya tetap maka disebut homoskedastisitas, dan jika berbeda maka terjadi heteroskedastisitas. Pengujian untuk melihat adanya gejala heteroskedastisitas dilakukan dengan uji Rank Spearman. Dasar pengambilan keputusan pada uji Rank Spearman adalah apabila nilai Sig > 0,05 maka tidak terjadi heteroskedastisitas, sebaliknya bila nilai Sig < 0,05 maka terjadi heteroskedastisitas. Dari hasil pengujian dengan menggunakan program SPSS 22.0 for windows dapat diketahui bahwa nilai signifikansi pada variabel sikap kewirausahaan sebesar 0,854>0,05 dan variabel karakteristik psikologi sebesar 0,809 > 0,05. Angka tersebut menunjukkan bahwa pada penelitian ini tidak terjadi heteroskedastisitas.

\section{Uji Hipotesis}

1. Pernyataan hipotesis:

1) Model I: Karakteristik Psikologi (X) memengaruhi Sikap Kewirausahaan (Z).

2) Model II: Karakteristik Psikologi (X) memengaruhi Intensi Kewirausahaan (Y).

3) Model III: Karakteristik Psikologi (X) dan Sikap Kewirausahaan (Z) memengaruhi Intensi Kewirausahaan (Y).

Kaidah pengambilan keputusan pada penelitian ini adalah apabila : Sig. $\geq$ 0,05 maka $\mathrm{H}_{0}$ diterima dan $\mathrm{H}_{\mathrm{a}}$ ditolak; sedangkan apabila Sig $<0,05$ maka $\mathrm{H}_{0}$ ditolak dan $\mathrm{H}_{\mathrm{a}}$ diterima.

2. Meregresi Model I, Model II dan Model III

1) Model I : Karakteristik Psikologi (X) memengaruhi Sikap Kewirausahaan (Z) 
Tabel 12 Hasil Regresi Model I

Coefficients $^{\mathrm{a}}$

\begin{tabular}{|c|c|c|c|c|c|c|}
\hline \multirow[b]{3}{*}{ Mode } & & \multicolumn{3}{|c|}{ Standardized } & \multirow[b]{3}{*}{$\mathrm{t}$} & \multirow[b]{3}{*}{ Sig. } \\
\hline & & \multicolumn{2}{|c|}{ Unstandardized Coefficients } & Coefficients & & \\
\hline & & B & Std. Error & Beta & & \\
\hline 1 & (Constant) & 1,561 &, 527 & & 2,959 &, 004 \\
\hline & $\mathrm{KP}$ &, 526 & ,163 & ,313 & 3,229 & ,002 \\
\hline
\end{tabular}

a. Dependent Variable: SK

Didapatkan persamaan regresi model I :

$Z=\rho m x X+\varepsilon 1$

$Z=0,313 X+0,902$

2) Model II : Karakteristik Psikologi (X) memengaruhi Intensi Kewirausahaan (Y)

Tabel 13

Hasil Regresi Model II

Coefficients $^{a}$

Standardized

\begin{tabular}{|c|c|c|c|c|c|c|}
\hline \multirow[b]{2}{*}{ Model } & & \multicolumn{2}{|c|}{ Unstandardized Coefficients } & Coefficients & \multirow[b]{2}{*}{$\mathrm{t}$} & \multirow[b]{2}{*}{ Sig. } \\
\hline & & $\mathrm{B}$ & Std. Error & Beta & & \\
\hline 1 & (Constant) & 1,558 &, 527 & & 2,959 & ,004 \\
\hline & $\mathrm{KP}$ & ,527 & ,163 & ,314 & 3,239 & ,002 \\
\hline
\end{tabular}

a. Dependent Variable: IK

Didapatkan persamaan regresi model II :

$Y=\rho m x X+\varepsilon 2$

$Y=0,314 X+0,902$

3) Model III : Karakteristik Psikologi (X) dan Sikap Kewirausahaan (Z) memengaruhi Intensi Kewirausahaan (Y)

Tabel 14 Hasil Regresi Model III

Coefficients $^{a}$

\begin{tabular}{|c|c|c|c|c|c|c|}
\hline \multirow[b]{3}{*}{ Model } & \multicolumn{6}{|c|}{ Standardized } \\
\hline & & \multicolumn{2}{|c|}{ Unstandardized Coefficients } & Coefficients & \multirow[b]{2}{*}{$\mathrm{t}$} & \multirow[b]{2}{*}{ Sig. } \\
\hline & & $\mathrm{B}$ & Std. Error & Beta & & \\
\hline \multirow[t]{3}{*}{1} & (Constant) & ,713 & ,465 & & 1,535 & ,128 \\
\hline & $\mathrm{KP}$ & 242 & , 145 & ,144 & 1,674 & ,098 \\
\hline & SK &, 541 & ,086 &, 542 & 6,287 &, 000 \\
\hline
\end{tabular}

a. Dependent Variable: IK 
Didapatkan persamaan regresi model III :

$Y=\rho m x X+\rho m x Z+\varepsilon 3$

$Y=0,144 X+0,542 Z+0,637$

Tabel 15

Rekapitulasi Regresi Model I, Model II dan Model III

\begin{tabular}{llll}
\hline Regresi & Koefisien Jalur & Signifikansi & Status \\
\hline $\mathrm{X} \rightarrow \mathrm{Z}$ & 0,313 & 0,002 & Signifikan \\
$\mathrm{X}$ & & 0,002 & Signifikan \\
\hline $\mathrm{X} \rightarrow \mathrm{Y}$ & 0,314 & 0,098 & $\begin{array}{l}\text { Tidak } \\
\mathrm{X}\end{array}$ \\
\hline $\mathrm{X}, \mathrm{Z} \rightarrow \mathrm{Y}$ & 0,144 & 0,000 & $\begin{array}{l}\text { Signifikan } \\
\text { Signifikan }\end{array}$ \\
$\mathrm{X}$ & 0,542 & & \\
\hline
\end{tabular}

3. Keputusan

Dasar pengambilan keputusan pada penelitian ini adalah sebagai berikut :

1) Bila variabel independen $(\mathrm{X})$ berpengaruh signifikan terhadap variabel mediasi (Z) ; serta koefisien variabel independen (X) dan variabel dependen (Y) sebelum dan sesudah memasukkan variabel mediasi (Z) tidak berubah dan tetap signifikan maka $\mathrm{H}_{0}$ diterima dan $\mathrm{H}_{\mathrm{a}}$ ditolak

2) Bila variabel independen $(\mathrm{X})$ berpengaruh signifikan terhadap variabel mediasi $(\mathrm{Z})$; serta koefisien variabel independen $(\mathrm{X})$ dan variabel dependen (Y) sebelum dan sesudah memasukkan variabel mediasi (Z) nilai koefisien turun maka $\mathrm{H}_{0}$ ditolak dan $\mathrm{H}_{\mathrm{a}}$ diterima

Berdasarkan tabel V. 15 di atas, dapat diketahui bahwa variabel independen (X) berpengaruh siginifikan terhadap variabel mediasi (Z). Selanjutnya koefisien jalur variabel karakteristik psikologi (X) dan intensi kewirausahaan (Y) sebelum memasukkan variabel sikap kewirausahaan (Z) adalah sebesar 0,314. Nilai tersebut menurun setelah memasukkan variabel sikap kewirausahaan (Z) yakni menjadi 0,144. Signifikansi juga berubah, sebelum memasukkan variabel sikap kewirausahaan (Z), persamaan regresi variabel karakteristik psikologi (X) terhadap intensi kewirausahaan (Y) signifikan. Namun setelah memasukkan variabel sikap kewirausahaan $(\mathrm{Z})$ berubah menjadi tidak signifikan. 
Oleh karena itu $\mathrm{H}_{\mathrm{a}}$ : ada pengaruh antara karakteristik psikologi terhadap intensi kewirausahaan dimediasi sikap kewirausahaan, diterima

4. Menentukan Jenis Mediasi

Penentuan jenis mediasi dilakukan apabila $\mathrm{H}_{\mathrm{a}}$ diterima. Mediasi menunjukan bagaimana sebuah variabel independen $(\mathrm{X})$ memengaruhi variabel dependen $(\mathrm{Y})$ melalui satu atau lebih variabel intervening yang dinamakan dengan variabel mediator (M). Selanjutnya berikut adalah kriteria sebuah variabel mediasi menjadi variabel mediasi penuh atau variabel mediasi parsial:

1) Mediasi penuh apabila koefisien variabel independen $(X)$ terhadap variabel dependen (Y) sebelum dan sesudah memasukan variabel mediasi (Z) nilainya turun dan tidak signifikan.

2) Mediasi parsial apabila koefisien variabel independen (X) terhadap variabel dependen (Y) sebelum dan sesudah memasukan variabel mediasi (Z) nilainya turun dan tetap signifikan.

Hasil uji hipotesis menunjukkan bahwa sesudah memasukkan variabel mediasi yakni sikap kewirausahaan (Z), nilai koefisien variabel karakteristik psikologi (X) terhadap variabel intensi kewirausahaan (Y) nilainya turun yang semula 0,314 menjadi 0,144 .

Selain itu status signifikansi juga berubah dimana sebelum memasukkan variabel sikap kewirausahaan $(\mathrm{Z})$, variabel karakteristik psikologi $(\mathrm{X})$ terhadap intensi kewirausahaan (Y) nilainya adalah signifikan, setelah memasukkan variabel mediasi yakni sikap kewirausahaan (Z) menjadi tidak signifikan. Oleh karena itu dapat disimpulkan bahwa pada penelitian ini jenis mediasi adalah mediasi penuh.

5. Menentukan Pengaruh Langsung dan Tidak Langsung

Langkah menentukan pengaruh langsung dan tidak langsung tidak dilakukan sebab langkah ini dilakukan apabila jenis mediasi merupakan mediasi parsial, sedangkan pada penelitian ini jenis mediasi merupakan mediasi penuh

\section{Pembahasan}

Berdasarkan proses di analisis penelitian untuk model I karakeristik psikologi berpengaruh terhadap sikap kewirausahaan. Kusmintarti et al. (2014) dalam 
penelitiannya mendukung temuan dalam proses ini. Dalam proses pada model II karakteristik psikologi berpengaruh terhadap intensi kewirausahaan. Hal ini dibuktikan dengan taraf signifikansi $0,002<0,05$. Pada model III karakteristik psikologi menjadi tidak signifikan terhadap intensi kewirausahaan setelah dimasukkan variabel sikap kewirausahaan ke dalam persamaan.

Keseluruhan proses tersebut bercirikan bahwa variabel independent (X) berpengaruh signifikan terhadap variabel mediasi $(\mathrm{Z})$; serta koefisien variabel independen (X) dan variabel dependen (Y) sebelum dan sesudah memasukkan variabel mediasi $(\mathrm{Z})$ nilai koefisien turun maka $\mathrm{H}_{0}$ ditolak dan $\mathrm{H}_{\mathrm{a}}$ diterima. Oleh karena itu dapat diambil kesimpulan bahwa ada pengaruh karakteristik psikologi terhadap intensi kewirausahaan dimediasi sikap kewirausahaan.

Hal ini didukung oleh penelitian yang dilakukan oleh Santoso dan Oetomo (2016) dimana hasil penelitian menunjukkan bahwa terdapat hubungan yang positif dan signifikan antara konstruk karakteristik psikologi dengan konstruk sikap kewirausahaan, dan konstruk sikap berwirausaha dengan konstruk niat kewirausahaan. Kusmintarti et al (2014) dalam hasil penelitiannya juga menunjukkan bahwa sikap kewirausahaan bertindak sebagai mediasi dari karakteristik kewirausahaan yang berpengaruh terhadap intensi kewirausahaan.

Dalam penelitian ini sikap kewirausahaan bertindak sebagai mediasi penuh. Karakteristik psikologi tidak mampu memengaruhi intensi kewirausahaan secara signifikan tanpa melalui variabel sikap kewirausahaan. Oleh karena itu karakteristik psikologi berpengaruh terhadap sikap kewirausahaan, selanjutnya sikap kewirausahaan berpengaruh terhadap intensi kewirausahaan. Ini berarti bahwa seseorang yang memiliki karakteristik psikologi seperti internal locus of control, propensity to take a risk, tolerance for ambiguity dan creativity cenderung memiliki respon terhadap kewirausahaan. Dengan kata lain karakeristik psikologi memengaruhi sikap kewirausahaan seseorang. Hal ini disebabkan karena dunia kewirausahaan lekat dengan kerja keras, pengambilan resiko, kreativitas, serta kemampuan dalam menghadapi situasi / kejadian yang tidak terduga. Sikap kewirausahaan selanjutnya memengaruhi intensi kewirausahaan seseorang. Ini berarti bahwa seseorang yang memiliki respon terhadap dunia kewirausahaan akan cenderung termotivasiuntuk merealisasikan bisnisnya. 
Oleh karena itu upaya yang dapat dilakukan untuk mendorong anak muda atau seseorang agar berwirausaha dimulai dari membangun karakteristik psikologinya. Hal ini karena karakteristik psikologi seseorang akan memengaruhi sikap kewirausahaan dan mendorong timbulnya intensi kewirausahaan. Intensi kewirausahaan inilah yang merupakan cikal bakal dari tindakan konkrit menjadi seorang wirausaha.

Karakteristik psikologi pada penelitian ini meliputi internal locus of control, propensity to take a risk, creativity dan tolerance for ambiguity. Seseorang yang memiliki internal locus of control tinggi berarti memiliki kemandirian yang besar sebab mereka yakin bahwa kegagalan maupun kesuksesan dalam hidupnya ditentukan oleh dirinya sendiri. Semakin mandiri seseorang dapat menciptakan sikap kewirausahaan yang pada akhirnya akan mendorong intensi kewirausahaannya. Seseorang yang memiliki propensity to take a risk atau kecenderungan dalam mengambil resiko yang tinggi berarti seseorang tersebut tidak takut untuk mengambil resiko. Seseorang yang tidak takut mengambil resiko dan mampu berjuang meskipun dalam situasi yang penuh dengan resiko akan menciptakan sikap kewirausahaan yang pada ujungnya akan mendorong intensi kewirausahaannya.

Seseorang yang memiliki kreativitas yang tinggi berarti memiliki kemampuan untuk mengembangkan ide baru maupun cara baru dalam melihat masalah serta peluang. Seseorang yang mampu menciptakan ide dari berbagai peluang maupun masalah tersebut akan menciptakan sikap kewirausahaan yang pada ujungnya akan mendorong intensi kewirausahaannya. Seseorang yang memiliki tolerance for ambiguity tinggi berarti bahwa seseorang tersebut mampu menghadapi dan menerima situasi yang tidak jelas. Seseorang yang makin bisa menerima dan berjuang pada lingkungan atau situasi tidak jelas akan menciptakan sikap kewirausahaan yang pada ujungnya akan mendorong intensi kewirausahaannya. Seseorang yang sudah memiliki intensi kewirausahaan apabila difasilitasi maka kewirausahaan di Indonesia dapat bertumbuh dan maju.

\section{Kesimpulan, Implikasi, Saran dan Keterbatasan}

\section{Kesimpulan}

1. Karakteristik psikologi mahasiswa di lima universitas Yogyakarta adalah tinggi.

2. Sikap kewirausahaan mahasiswa di lima universitas Yogyakarta adalah sangat 
tinggi.

3. Intensi kewirausahaan mahasiswa di lima universitas Yogykarta adalah sangat tinggi.

4. Ada pengaruh karakteristik psikologi terhadap intensi kewirausahaan dimediasi sikap kewirausahaan pada mahasiswa di lima universitas Yogyakarta

\section{Implikasi}

1. Pada penelitian ini responden berjumlah 100 mahasiswa, namun pada perjalanannya data yang dapat diolah hanya data dari 98 responden saja. Hal ini disebabkan karena terdapat 2 data yang rusak. Peneliti menyarankan bagi penelitian selanjutnya agar dapat mendeteksi sedini mungkin kuesioner yang tidak diisi dengan lengkap.

2. Responden pada penelitian ini berasal dari lima universitas di Yogyakarta yakni Universitas Gadjah Mada, Universitas Islam Negeri Sunan Kalijaga, Universitas Sanata Dharma, Universitas Atma Jaya Yogyakarta, dan Universitas Sarjanawiyata Tamansiswa. Peneliti menyarankan bagi penelitian selanjutnya untuk mengembangkan ruang lingkup populasi.

3. Responden pada penelitian ini berasal dari mahasiswa di lima universitas Yogyakarta dengan jumlah sampel 100 mahasiswa yang kemudian saat olah data berubah menjadi 98 responden. Peneliti menyarankan bagi penelitian selanjutnya untuk menambah jumlah sampel sehingga sampel yang diambil pada masing masing universitas dapat lebih mewakili lagi.

4. Penelitian ini hanya menggunakan variabel karakteristik psikologi untuk mengetahui pengaruh terhadap sikap kewirausahaan dan dampaknya terhadap intensi kewirausahaan. Peneliti menyarankan untuk menambah variabel lain pada penelitian selanjutnya, sehingga dapat diketahui faktor-faktor lain yang dapat memengaruhi sikap kewirausahaan dan dampaknya terhadap intensi kewirausahaan selain faktor karakteristik psikologi

\section{Keterbatasan}

1. Peneliti tidak dapat mendeteksi sedini mungkin data yang rusak, sebab kuesioner tidak diisi dengan lengkap. Oleh karena itu pada perjalanannya hanya 98 data 
yang dapat diolah.

2. Penelitian ini adalah penelitian studi kasus (case study) pada mahasiswa di Universitas Gadjah Mada, Universitas Islam Negeri Sunan Kalijaga, Universitas Sanata Dharma, Universitas Atma Jaya Yogyakarta, dan Universitas Sarjanawiyata Tamansiswa, sehingga belum tentu dapat digeneralisasikan ke ruang lingkup yang umum.

3. Penelitian ini hanya meneliti 100 mahasiswa yang pada perjalanannya menjadi 98 data yang diolah dari 114.225 populasi yang ada, dengan tingkat kepercayaan $98 \%$ dan tingkat error sebesar 10\%, sehingga sampel belum sepenuhnya dapat mewakili seluruh jumlah populasi yang ada serta hasil penelitian bisa beresiko memiliki tingkat error yang besar.

4. Peneliti hanya menggunakan variabel karakteristik psikologi pada variabel independennya, sehingga tidak dapat mengetahui faktor lain yang dapat memengaruhi sikap kewirausahaan dan dampaknya terhadap intensi kewirausahaan

\section{Referensi}

Abdurrahman, Maman. Muhidin, Sambas Ali. 2011. Panduan Praktis Memahami Penelitian (Bidang Sosial - Administrasi - Pendidikan), Bandung : CV Pustaka Setia

Agustina, Tri S. 2019. Kewirausahaan di Era Revolusi Industri 4.0, Jakarta: Mitra Wacana Media

Ajzen, I. 1991. The Theory of Planned Behavior. Organizational Behavior and Human Decision Process. Vol.50 p.179-211

Anik K, Armanu T, Khusnul A, dan Ghozali M. 2014. "The Relationships Among Entrepreneurial Characteristic, Entrepreneurial Attitude, and Entrepreneurial Intention," Journal of Business and Management, Juni, 26.

Aurellia, Dinda P. 2019. Pengaruh Persepsi Konsumen pada Store Atmosphere Terhadap Impulse Buying Behavior Melalui Shopping Emotion Pleasure. Yogyakarta

Barringer, Bruce R, R. Duene Ireland. 2016. Entrepreneurship: Successfully Launching New Ventures England : Pearson Educattion Limited

Bux, Soomro R. Honglin, Yuan. 2015. 'Analyzing the Impact of The Psychological Characteristics on Entrepreneurial Intentions Among University Students," Advances in Economics and Business, 3 (6), 215-224.

Crider, A.B. 1983. Psychology. Scott, Foresman \& Company

Darmanto, Susetyo. 2012 "Peran Sifat Personalitas (Personality Trait) Dalam Mendorong Minat Berwirausaha Mahasiswa", 1, 30-45

Dewi, Agustina Kartika. 2014. Pengaruh Locus of Control dan Motivasi Belajar Terhadap Prestasi Belajar Akuntansi. Yogyakarta 
Dharmawati, Made. 2016. Kewirausahaan. Jakarta : PT RajaGrafindo Persada Furnham, Adrian. Marks, Joseph. 2013. "Tolerance Of Ambiguity : A Review of the Recent Literature." Journal of Psychology, 9, 717-728

Indrawan, Rully. Poppy, Yaniawati. 2014. Metodologi Penelitian Kuantitatif, Kualitatif, dan Campuran untuk Manajemen, Pembangunan, dan Pendidikan, Bandung: PT Refika Aditama.

Koh, H.C. 1996 “Testing hypotheses of entrepreneurial characteristics", Journal of Managerial Psychology, 12-25

Murni, Devika Sumar Nindya. 2017. Hubungan Internal Locus of Control dengan Minat Berwirausaha pada Mahasiswa. Malang

Rangkuti, Anna Armeini. 2017. Statistika Inferensial: Untuk Psikologi dan Pendidikan. Jakarta : Kencana.

Riduwan, Engkos A. Kuncoro. 2013 Cara Menggunakan dan Memaknai Path Analysis (Analisis Jalur), Bandung : Penerbit Alfabeta

Rotter, J.B. 1966. Genaralized Expectancies for Internal Versus External Control of Reinforcement. Pshycologycal Monographs. Vol. 80, pp. 128

Rusdiana. 2014. Kewirausahaan: Teori dan Praktik. Bandung : CV Pustaka Setia Sarwono, Sarlito W. 2009. Pengantar Psikologi Umum. Jakarta : PT RajaGrafindo Persada

Shara, Assem, Alaa El-Gharbawy, \& Mohamed A. Raghep. 2018. "Factors That Influence Entrepreneurial Intention within University Students in Egypt", Open Access Library Journal, 10 (10), 1-14

Sugiyono, 2018. Metode Penelitian Kuantitatif. Bandung : Penerbit Alfabeta Suryana, 2013. Kewirausahaan : Kiat dan Proses menuju Sukses ed. 4. Jakarta : Salemba Empat.

Santoso, Singgih , \& Budi Sutedjo Dharma Oetomo. 2016. "Pengaruh Karakteristik Psikologi, Sikap Kewirausahaan, dan Norma Subyektif terhadap Niat Berwirausaha," Jurnal Manajemen, (10), 338 -352.

\section{Situs Web}

Nofie Tessar. Soetrisno Bachir Ajak Generasi Muda Berwirausaha untuk Mewujudkan Kesejahteraan Nasional https://www.liputan6.com. Diakses tanggal 4 Oktober 2019 Pukul 14.58.

Fabian Januarius Kuwando. Jumlah Entrepreneur di Indonesia Jauh di Bawah Negara Maju, Ini Kata Jokowi. https://nasional.kompas.com..Diakses tanggal 04 Oktober 2019 Pukul 15.11

Fika Nurul Ulya. Indonesia Masih Butuh 4 Juta Entrepreneur Baru. https://money.kompas.com/. Diakses hari Senin 21 Oktober 2019

Nidia Zuraya. Enggartiasto : Tingkat Kewirausahaan di Indonesia Rendah. https://republika.co.id/berita/ekonomi/korporasi. Diakses hari Rabu 23 Oktober 2019 pukul 17.00

https://www.ugm.ac.id. Diakses hari Selasa 03 Maret 2020 pukul 17.17.

http://www.uin-suka.ac.id/. Diakses hari Selasa 03 Maret 2020 pukul 19.15 